\title{
“DEAR EMMA...". GENRE OVERLAPPING AND REGISTER VARIATION IN THE ENGLISH AND ITALIAN VERSION OF SERGIO MARCHIONNE'S LETTER TO CONFINDUSTRIA ${ }^{1}$
}

\section{PIETRO MANZELLA, PhD}

Association for International and Comparative Studies in the field of Labour Law and Industrial Relations (ADAPT) Via Garibaldi 7, 24124, Bergamo, Italy pietro.manzella@adapt.it

ORCID: https://orcid.org/0000-0001-8785-1825

\begin{abstract}
The aim of this paper is to examine whether genre overlapping and register variation have implications in terms of translation outcomes. To this end, the English and the Italian version of the letter sent by Sergio Marchionne to the President of Confindustria - Italy's most important employers' organisation - will be analysed. The decision to investigate Marchionne's statement is based on the fact that this is a letter disseminated as a press release, which also contains highly-technical terminology pertaining to the discourse
\end{abstract}

\footnotetext{
${ }^{1}$ The author wishes to thank the reviewers for their useful feedback.
} 


\title{
Pietro Manzella: “Dear Emma”... Genre Overlapping...
}

of Employment Relations (ER). It is stressed that a number of issues arise when deciding which genre and register to use when translating specialised texts. It is argued that genre overlapping and register variation affect the texts in English and Italian in important respects, leading to different perceptions on the part of the target audience.

Keywords: genre analysis; register; employment relations; translation; linguistics.

\section{“DEAR EMMA...". ZAZĘBIANIE SIĘ GATUNKÓW I WARIANCJA REJESTRÓW W ANGIELSKIEJ I WLOSKIEJ WERSJI LISTU SERGIA MARCHIONNE DO CONFINDUSTRII}

Streszczenie: Celem artykułu jest zbadanie, czy zazębianie się gatunków i wariancja rejestrów mają wpływ na rezultat tłumaczenia. W tym celu analizie poddaje się angielską i włoską wersję listu Sergia Marchionne do prezesa Confindustrii - głównej organizacji pracodawców we Włoszech. Decyzja o wyborze pisma Marchionne wynika $\mathrm{z}$ faktu, że list ten jest rozpowszechniany jako komunikat prasowy, a jednocześnie zawiera wysoce specjalistyczną terminologię dotyczącą języka używanego w zakresie stosunków pracy (Employment Relations, ER). Autor zwraca uwagę na fakt, że podejmując decyzję o wyborze gatunku i rejestru podczas thumaczenia tekstów specjalistycznych, należy uwzględnić szereg kwestii. Twierdzi, że zazębianie się gatunków i wariancja rejestrów wpływają w istotnych aspektach na teksty w językach angielskim i włoskim, w wyniku czego odbiorcy postrzegają je w różny sposób.

Słowa kluczowe: analiza gatunków; rejestr; stosunki pracy; przekład; językoznawstwo.

\section{"CARA EMMA...". SOVRAPPOSIZIONE DI GENERE E VARIAZIONE DI REGISTRO NELLA VERSIONE IN INGLESE E ITALIANO DELLA LETTERA DI MARCHIONNE A CONFINDUSTRIA}

\begin{abstract}
Il presente contributo esamina gli effetti che la sovrapposizione di genere e la variazione di registro possono avere sul processo di traduzione. A tal fine, viene proposta una analisi della versione in lingua italiana e inglese della lettera inviata da Marchionne, l'allora amministratore delegato della Fiat, al presidente di Confindustria, la principale associazione datoriale in Italia. Il messaggio di Marchionne è peculiare in quanto trattasi di un comunicato stampa caratterizzato da un tipo di terminologia altamente specialistica. Ciò che emerge è la presenza di una serie di criticità laddove il contenuto della
\end{abstract}


lettera viene tradotto dall'italiano all'inglese, che generano una diversa percezione da parte del lettore straniero rispetto agli aspetti discussi nel testo di partenza.

Parole chiave: analisi di genere; registro; relazioni industriali; traduzione; linguistica.

\section{Overview}

On 30 September 2011, Sergio Marchionne - who at the time was the CEO of FIAT and Chairman of FIAT Industrial Spa - addressed a letter to Emma Marcegaglia, the then President of Confindustria, announcing the decision to leave Italy's largest employers' organisation. FIAT's withdrawal was a historic decision and attracted a lot of attention in the media, particularly considering that FIAT had been a long-standing member of Confindustria. The letter followed the conclusion of the agreement between Confindustria and a number of trade unions on 21 September 2011, which marked a turning point in employment relations (ER) in Italy - and above all the approval by Parliament of a specific provision (Article 8) establishing among other things that the June agreement would apply retroactively. Marchionne motivated FIAT's decision with the fact that the new terms placed limitations on Italian companies operating in the international markets, particularly in terms of employment relations and flexible working arrangements. The letter to Confindustria hit the headlines in the national and international press, as it was disseminated in the form of a press release, in both English and Italian.

These two versions of the text will be examined in this paper, which aims to investigate the linguistic aspects of the English and the Italian document issued by FIAT. Specifically, the paper explores the extent to which genre overlapping and register variation play a role in translation. To this end, a critical analysis will be provided of the terms used in the two versions, also focusing on ER terminology, which characterises many passages of the letters. As this is a specialised domain (Bromwich and Manzella 2018), ER features linguistic peculiarities that need to be taken into account when rendering terms denoting distinctive practices and institutions. This assumption is based on the fact that discourse is closely linked to the sociocultural context 


\section{Pietro Manzella: “Dear Emma”... Genre Overlapping...}

in which it is constructed. Consequently, its interpretation relies to a large extent on the contextual constraints of the event in which it is expressed or received, cultural elements representing an essential part of these contextual constraints as they influence both the discursive organisation and the choice of realisation (Gotti 2007). These peculiarities will be scrutinised at length, examining whether genre overlapping and register variation have an impact on the effectiveness of the translation, the degree of equivalence between the source text (ST) and the target text (TT), and the extent to which context-specific terms are likely to be understood by TT readers. The remainder of this paper is organised as follows. An analysis of the existing literature on this topic will be provided in section 2 , followed by a close examination of the documents selected for analysis (section 3). Finally, section 4 will comment on the main findings, making suggestions for future research.

\section{Literature Review}

Previous linguistics research has considered CEO letters and Chairman statements from different perspectives. In some cases, metadiscourse has been the main focus of investigation (Garzone 2007, Gillaerts and Van de Velde 2011, Huang and Rose 2018, Hyland 1998). In this sense, it has been stressed that the CEO is now expected to set the tone, shape the corporate culture, and outline a vision for the future.

This is because effective CEO communication has become essential to the management and financial performance of the corporation (Ngai and Singh 2014). The aim of the CEO letter may be said to project a positive image of the company and to raise the profile of the CEO. Thus company reporting is an important genre, especially when it is aimed at a public audience by a large corporation (Kong 2014). CEO communication has also been examined by means of text analysis (Karlsson and Rutgersson 2014, Loewenstein, Ocasio and Jones 2012, Murphy 2015). A particular focus has been placed on the vocabulary used by CEOs, with the result that more nuanced conceptualisations of the role of corporate terminology are emerging (Craig and Amernic 2014). The function of the CEO's message is to provide the investment community and the general public with information and to construct a positive relationship with them. Each of 
these functions may be more or less explicit and emphasised, but both are always present (Schnizter 2017).

In addition, the terminology used in the CEO letter is intended to reflect and reinforce core organisational values, to highlight shared experience, to indicate opportunities and point to challenges to be overcome, while promoting a common organisational identity and commitment (Ilie 2017). Other scholars have looked at CEO discourse as a way to generate legitimation, which is understood as an ideological space within which the institution can operate, enjoying sufficient social acceptance to freely pursue its activities (Breeze 2013). Persuasion is another aspect that has been analysed in CEO statements. In this sense, it has been argued that these messages carefully set out their assessment of situations and events. As a rule, they construct their arguments so rationally that it is difficult to challenge them (Amernic and Craig 2006). In other words, perceptions and ideologies are shaped by means of a language game (Clifton 2012).

Finally, multilingual CEO letters have been examined from a translation perspective (Neumann 2014). Specifically, textual conventions need to be adapted to meet cultural expectations concerning the degree of certainty with which an assertion is made (Kranich 2016). The problem of equivalence has also been discussed, in that the functions that the source language text fulfils for a ST audience can only be maintained if the translator makes adaptations to enable the text to work in the same or a comparable way for a TT reader (Kranich 2016). It should be noted that the considerable body of work produced in this domain mostly deals with CEO discourse in which the target group consists of shareholders or stakeholders (in particular, employees, suppliers and customers). Building on these previous contributions, this paper aims to take a step further, examining the linguistic aspects of a letter sent by a CEO to the president of an employers' organisation, i.e. Confindustria.

\section{Discussion}

This paper considers the English and Italian version of the letter sent by Marchionne Confindustria in September 2011. The two documents reproduced in Appendix $\mathrm{A}$ and $\mathrm{B}-$ will be examined through a 


\section{Pietro Manzella: “Dear Emma”... Genre Overlapping...}

contrastive analysis approach, which has been widely applied to translation in connection with different language pairs (Gast 2015; Ke 2018). Contrastive analysis has proved most useful in pointing out areas where direct translation of a term or a phrase fails to accurately convey in the target language the meaning intended in the source text (Hassan 2014). More recently, contrastive analysis has become more descriptive and theoretical, and it has taken language use into account, to compare frequencies and distributions, as well as structures (Aijmer and Lewis 2017). Contrastive analysis has been used in particular to study elements which are multifunctional and cases in which the meaning is not entirely clear. This is because the translated text may give rise to issues in terms of polysemy, multi-functionality, core meaning and the distinction between meaning and function (Aijmer and Altenberg 2013). The terminology examined was selected considering the following criteria. When investigating genre overlapping, the candidate terms were identified by looking at the Italian version of the text, manually extrapolating those pertaining to specialised communication - industrial relations in our case - understood as expert-to-expert communication or communication in which at least the text producer has full expert status with regard to the topics covered (Schubert 2007). The terms chosen were then investigated to see how they were rendered in English. As for register variation, the two versions were contrasted, analysing those passages in which a clear difference emerged in relation to register use.

For the purposes of this study, it was assumed that the letter was originally drafted in Italian and then translated into English, taking account of the fact that both Marchionne (the sender) and Emma Marcegalia (the recipient) speak Italian as their first language, although Marchionne was in fact bilingual, having lived in Canada for many years before returning to Italy.

\subsection{Genre Overlapping}

The letter by Marchionne is characterised by a degree of genre overlapping. It contains elements of economic, ER, and political discourse, bringing to mind Bhatia's notion of interdiscursivity, which has been defined as the appropriation of contextual and text-external 
generic resources within and across professional genres and professional practices (Bhatia 2004, 2008, and 2010). An awareness of interdiscursivity is key to understanding the complexities and the objectives of professional communication and to providing the opportunity for shared meaning and mutual understanding across a diverse audience (Gill 2011). It should also be noted that the message was disseminated in the form of a press release, which is usually drafted to inform the general public. More generally, one should understand the importance of framing complex issues (Lakoff 2009) in a way that is not only accurate, but also accessible to a lay readership (French and Watt 2018). Finally, it bears highlighting that the document under examination is a letter intended for both the primary addressee (the Confindustria President) and the secondary addressee (the investment community and the general public). This aspect should also be considered, in that it might give rise to communication issues as different readers may receive different messages from the text, and even the same reader may interpret the meaning differently on a second or third reading (Bloor and Bloor 2007).

The hybrid nature of the text - a letter disseminated in the form of a press release - might affect translation. Furthermore, the text is intended for a diverse audience and features a blend of technical and non-technical terminology. Consequently, some issues emerge when translating this text into another language, because doubts arise as to how to deal with it. Marchionne's letter was produced in press release format, i.e. it was ultimately intended to reach the general public. While the corporate press release - which constitutes an important sub-genre within the overall press release genre - has not yet been clearly characterised (Crawford Camiciottoli 2013), it certainly aims to meet the criteria of explanatory force and clarity (Malavasi 2011). In this sense, one might question the assumption that some concepts pertaining to specialised discourse (ER in our case) are shared knowledge, so they do not need expanding in the target language.

One example of this is 'Confindustria', which as noted above is the name of the largest employers' organisation in Italy. The word which appears several times throughout the text - is always left in Italian in the English version of the document, without providing any explanation (an example of this is to be found in line 5 of the English version). While most Italian readers - including of course the primary addressee - are familiar with this concept, doubts arise as to whether international readers - to which the English version is directed - are 


\section{Pietro Manzella: “Dear Emma”... Genre Overlapping...}

aware of the Italian system of representation. Using words from the ST in the TT language runs counter to the objective of press statements, which should be developed in a manner engaging the media with a newsworthy subject presented in a clear and compelling manner (Morrow, Hirano and Christensen 2008).

The same observation may be made in relation to another concept pertaining to ER terminology, i.e. accordo interconfederale, which is used extensively throughout the text. An accordo interconfederale can be defined as a collective agreement concluded by the employee and employer organisations, applicable to an entire sector of the economy (industry, commerce, agriculture) (EUROFOUND 2003). Unlike 'Confindustria', which was not translated, accordo interconfederale was rendered with the English 'interconfederate agreement' (line 4 of the English version). In other words, a literal translation was used. Even though in one case it was specified that the agreement was signed by 'national trade unions' (line 4 of the English version) the advisability of leaving this word in Italian in the TT might be questioned, because it frustrates the attempt of press releases to adopt language which is readily understood by a non-specialised audience.

This is true especially in consideration of the fact that literal translations can sometimes result in awkward expressions that puzzle readers from both cultures (Liu, Volcic and Gallois 2015). Further explanation would have been necessary to make sure this concept was readily understood. Alternatively, the recourse to different terminology in the TT might have served the purpose of ensuring clarity. A different rendering of accordo interconfederale could have been 'national multiindustry agreement' which, although less literal, seems to better convey the meaning of this concept in the TT. In passing, it could also be noted that in addition to accordo, another term was used in the Italian version of the letter to refer to this concept, intesa. Both accordo and intesa (line 4 and line 6 of the Italian version, respectively) were translated into English as 'agreement' (lines 4 and 7 of the English version). While this terminology is perfectly acceptable, a different word could have helped international readers to recognise the distinction between the types of agreements concluded. In this sense, it is worth recalling that "consistency of register, together with what has been referred to as internal cohesion, is what makes a text hang together, function as a unit in its environment" (Hatim and Munday 2004: 191).

Unlike the lexical items examined so far, some concepts were expanded in the English version, in order to make them understandable 
to an international audience consisting of both specialists and laypersons. In other words, a different approach was adopted, which affected the translation outcome. For example, flessibilità (flexibility) in the Italian letter became 'labour flexibility' in the English version (line 6). The aim in this case is to specify that the changes made to Article 8 do not affect all types of flexibility, a concept so diluted that can mean everything and nothing (Stråth 2000). Rather, Marchionne referred to labour or workforce flexibility, which Fairclough has characterised as pertaining to neo-liberal discourse (Fairclough 2010) and which was based on concepts such as 'lean production', 'slimming down', 'the flexible company', and 'outsourcing' (Magnusson and Stråth 2016).

Consequently, while in the Italian version, reference is made to the general concept of 'flexibility', the concept is expressed in greater detail in the English version, as the flexibility mentioned here is the one concerning the workforce. A different approach is therefore used in terms of domain-specific concepts.

\subsection{Register Variation}

In addition to genre overlapping, the Italian and the English versions of the letter examined in this paper are characterised by variation in terms of register. In other words, sometimes there is a minimal correspondence between the style used in the ST and that adopted in the TT. Along with language contrast and translation decisions, register differences can give rise to issues with respect to variation between originals and translations (Neumann 2014). Halliday defines register as a configuration of meanings that are typically associated with a particular situational configuration of field, mode and tenor (Halliday 1985). However, register also has a bearing on genre, in that different genres are observed to have different degree of formality (Fang, Cao 2015). In some cases, the register used in the TT features higher levels of formality than the one chosen for the ST. The following passage from the Italian version of Marchionne's letter concerning workers' rights clearly illustrates this point: $i$ rapporti con $i$ nostri dipendenti e con le Organizzazioni sindacali saranno gestiti senza toccare alcun diritto dei lavoratori (line 30 and 31 of the Italian version. Our translation: 


\section{Pietro Manzella: “Dear Emma”... Genre Overlapping...}

Relations with our employees and with the trade unions will be handled without affecting any of the workers' rights). Toccare (line 30) literally 'to touch' - was used in a figurative sense to mean 'to affect'. The English translation reads as follows: "Relations with our employees and with the trade unions will be conducted in a manner that does not infringe on any rights of workers". In the TT, 'to infringe on' was used to render the Italian toccare (line 31 of the English version). In considering three levels of formality, viz. formal, neutral and informal (Wallwork 2016), toccare can be seen as having a neutral degree of formality. On the contrary, 'to infringe on' is an expression mostly employed in formal communication (Cambridge Dictionary 2020).

Another example of register variation between the Italian and the English version of the letter is to be found at the beginning of the second paragraph, when Marchionne pointed out that La Fiat fin dal primo momento ha dichiarato a Governo, Confindustria $e$ Organizzazioni sindacali il pieno apprezzamento per $i$ due provvedimenti (line 8 of the Italian version). Our translation: 'From the very beginning, FIAT expressed its full appreciation to the government, Confindustria and trade unions for the two provisions'.

Significantly, pieno apprezzamento was translated into English as 'unreserved appreciation' (line 8 of the English version), where 'unreserved' is a formal adjective meaning 'without any doubts or feeling uncertain; total' (Cambridge Dictionary 2020). 'Unreserved' is characterised by a higher level of formality than 'full', which in this context could be seen as the closest equivalent of the Italian pieno.

The same holds true for utilizzare (line 28, lit. 'to use', 'to utilize', or 'to make use of') which appears in the following sentence of the Italian version: Da parte nostra, utilizzeremo la libertà di azione applicando in modo rigoroso le nuove disposizioni legislative (Our translation: 'On our side, we will make use of our freedom of action to rigorously implement the new provisions). In the English version of the letter to Confindustria, this sentence reads as follows: 'On our side, we will exercise our freedom to rigorously apply the new legislative provisions' where 'exercise' (line 29) is more formal than 'use' or 'utilize', which would have been closer to the ST meaning.

These lexical items appear to imply that the English version adopts more formal terminology than the Italian one. Yet this is not always the case, because in some cases the terms used in the ST are characterised by a higher degree of formality than the terms in the TT. Lines 17 and 18 of the Italian version of the letter by Marchionne read 
as follows: un acceso dibattito che [...] ha fortemente ridimensionato le aspettative sull'efficacia dell'Articolo 8 (Our translation: a lively debate which [...] has played down expectations about the efficacy of Article 8). There exist a number of options to render efficacia in English, e.g. effectiveness, efficacy, validity, strength, with the first two words frequently used as synonyms (Zoppei 2017). The English version of the text under examination here makes use of 'effectiveness' (line 17) to translate efficacia, which is less formal than 'efficacy' (Cambridge Dictionary 2020) and might also take on a different meaning. Specifically, 'efficacy' is the ability to get things done and meet targets. The focus of efficiency is on the achievement of the result, not on the resources spent to achieve the desired result.

'Effectiveness' in this context means doing the right things, setting the right targets to achieve an overall goal and including the elements in the process. As a result, what is effective is not necessarily efficacious (Addink 2019).

\section{Conclusion}

This paper has examined the English and the Italian version of the letter by Sergio Marchionne, the then FIAT CEO and Chairman of FIAT Industrial Spa, to Emma Marcegaglia, who at the time was the President of Confindustria, Italy's largest employers' organisation.

The message is of a hybrid nature, in that it features the characteristics of both a letter and a press release, while containing specialised terminology pertaining to ER discourse. This combination of different genres - which Bhatia has termed 'interdiscursivity' resulted in different and sometimes opposing translation strategies. In some cases, the text was treated as if it were a letter -i.e. peer-to-peer communication - between two professionals operating in the same field. For this reason, certain domain-specific items were taken for granted, so they were either left untranslated (e.g. 'Confindustria') or rendered literally (i.e. accordo interconfederale). In other cases, the need to ensure clarity prevailed, as is usually the case with press releases. Consequently, attempts were made in the English version of the message to break down certain notions that the non-specialist reader could find difficult to appreciate. The attempt to simplify specialised 


\section{Pietro Manzella: “Dear Emma”... Genre Overlapping...}

concepts for a wider readership has been defined as 'popularisation', i.e. "making specialised knowledge accessible to non-specialised readers for information purposes" (Gotti 2014: 14). In the letter examined in this paper, the popularisation process seems to take place in the translation from one language to another, in the sense that some terms which are specific to ER discourse in the source language are made more accessible in the target one. However, the use of different translation strategies tends to make the TT more difficult and ambiguous, at times affecting clarity.

In addition to genre overlapping, register variation might also alter the effectiveness of communication. Striking the right note in terms of the tenor of discourse in the translation can be difficult, because it depends on whether the translator perceives a certain level of formality as 'right' from the perspective of the source culture and the target culture (Baker 2011). The lexical items examined ('effectiveness', 'to infringe on') point to a divergence between the ST and the TT in terms of register. While there is little change in meaning, an upward or a downward register shift might affect reader perception. For instance, the translation of a general, stylistically neutral word with a more specific, value-laden term may contribute to a change in the narrative standpoint, by bringing the textual world closer to the reader (Shuttleworth and Cowie 2014). Furthermore, register variation might be interpreted as an attempt to increase or decrease the relevance of the issue being discussed (Neumann 2014) i.e. workers' rights and the efficacy of the law in the text examined here. Consequently, readers of the English text, which is characterised by more formal terminology, might treat the issues discussed in the letter more seriously than their Italian counterparts. It is a matter of speculation whether genre overlapping and register variation were the result of a deliberate choice. Yet they affect the texts drafted in English and Italian in important respects, in that they might be perceived differently by the target audience, be they professionals or non-specialist readers. Future research might consider examining other press releases by CEOs published in two different languages over a specific timeframe, to see if they too are characterised by genre overlapping and register variation, evaluating the possible impact of these linguistic phenomena on the effectiveness of translation. 


\section{Bibliography}

Addink, Henk. 2019. Good Governance: Concept and Context. Oxford: Oxford University Press.

Aijmer, Karin and Bengt Altenberg, eds. 2013. Advances in Corpusbased Contrastive Linguistics: Studies in honour of Stig Johansson - Studies in Corpus Linguistics. Amsterdam: Benjamins.

Aijmer, Karin, and Diana Lewis. 2017. Contrastive Analysis of Discourse-pragmatic Aspects of Linguistic Genres. Cham: Springer.

Amernic, Joel H., and Craig Russell, eds. 2006. CEO-Speak: The Language of Corporate Leadership. Montreal: McGillQueen's University Press.

Baker, Mona. 2011. In Other Words: A Coursebook on Translation, $2^{\text {nd }}$ ed. Abingdon: Routledge.

Bhatia, Vijay K. 2004. Worlds of Written Discourse: A Genre-based View. London: Continuum International.

Bhatia, Vijay K. 2008. Genre analysis, ESP and professional practice. English for Specific Purposes 27: 161-174.

Bhatia, Vijay K. 2010. Interdiscursivity in Professional Communication. Discourse \& Communication 4: 32-50.

Bloor, Meriel and Bloor, Thomas. 2007. The Practice of Critical Discourse Analysis: an Introduction. Abingdon: Routledge.

Breeze, Ruth. 2013. Corporate Discourse. London: Bloomsbury.

Bromwich, William and Manzella, Pietro. 2018. Shock Absorbers, Tax Wedges and White Resignations: Language Challenges in Comparative Industrial Relations. The Translator 24: 70-88.

Cambridge

Dictionary.

2020.

Efficacy. $<$ https://dictionary.cambridge.org/it/dizionario/inglese/efficac y> (accessed 3 March 2020).

Cambridge

Dictionary. 2020. Infringe on. $<$ https://dictionary.cambridge.org/it/dizionario/inglese/infring e-on-upon-sth?q=infringe+on\%2Fupon+sth> (accessed 15 March 2020).

Cambridge Dictionary. 2020. Unreserved. https://dictionary.cambridge.org/it/dizionario/inglese/unreserv ed (accessed 20 March 2020). 
Pietro Manzella: “Dear Emma”... Genre Overlapping...

Clifton, Jonathan. 2012. 'Doing' Trust in Workplace Interaction. In Professional Communication across Languages and Cultures, eds. Stanca Măda and Răzvan Săftoiu, 107-134. Amsterdam: John Benjamins.

Craig, Russell and Amernic, Joel H. 2014. Exploring Signs of Hubris in CEO Language. In Communication and Language Analysis in the Corporate World, ed. Roderick P. Hart. 69-88. Hershey: Information Science Reference.

Crawford Camiciottoli, Belinda. 2013. Rhetoric in Financial Discourse. A Linguistic Analysis of ICT-mediated Disclosure Genres. Amsterdam: Rodopi.

EUROFOUND. 2003. National Multi-Industry Agreement.

$<$ https://www.eurofound.europa.eu/efemiredictionary/national -multi-industry-agreement-0> (accessed 15 January 2020).

Fang, Chengyu Alex, and Jing Cao. 2015. Text Genres and Registers: The Computation of Linguistic Features. Berlin: Springer.

Fairclough, Norman. 2010. Critical Discourse Analysis: The Critical Study of Language. London: Routledge.

French, Peter, and Dominic Watt. 2018. Assessing Research Impact in Forensic Speech Science Casework. In Applying Linguistics. Language and the Impact Agenda, eds. Dan McIntyre and Hazel Price, 150-162. Abingdon: Routledge.

Garzone, Giuliana. 2007. Annual Company Reports and CEOs' Letters:

Discoursal Features and Cultural Markedness". In Intercultural Aspects of Specialised Communication: 14. Linguistic Insights - Studies in Language and Communication, eds. Christopher N. Candlin and Maurizio Gotti, 311-342. Bern: Peter Lang.

Gast, Volker. 2015. On the use of Translation Corpora in Contrastive Linguistics. A Case Study of Impersonalisation in English and German. Language in Contrast 15: 4-33.

Gillaerts, Paul and Van de Velde, Freek. 2011. Metadiscourse on the Move: The CEO's letter revisited. In Discourse, Communication and the Enterprise. Genres and Trends, eds. Giuliana Garzone and Maurizio Gotti, 151-168. Bern: Peter Lang.

Gill, Robert. 2011. Using Storytelling to Maintain Employee Loyalty during Change. International Journal of Business and Social Science 2: 23-32. 
Gotti, Maurizio. 2007. Introduction. In Intercultural Aspects of Specialised Communication: 14. Linguistic Insights - Studies in Language and Communication, eds. Christopher N. Candlin and Maurizio Gotti, 9-26. Bern: Peter Lang.

Gotti, Maurizio. 2014. Reformulation and Recontextualisation in Popularisation Discourse. Ibérica 27: 15-34.

Halliday, Michael A. K. 1985. Introduction to Functional Grammar. London: Edward Arnold.

Hassan, Bahaa-eddin Abulhassan. 2014. Between English and Arabic. A Practical Course in Translation. Newcastle upon Tyne: Cambridge Scholars Publishing.

Hatim, Basil and Munday, Jeremy. 2004. Translation: An Advance Resource Book. Abingdon: Routledge.

Huang, Ying, and Kaye Rose. 2018. You, Our Shareholders: Metadiscourse in CEO Letters from Chinese and Western Banks. Text \& Talk 38: 167-190.

Hyland, Ken. 1998. Exploring Corporate Rhetoric: Metadiscourse in the CEO's Letter. International Journal of Business Communication 35: 224-244.

Ilie, Cornelia. 2017. Leaders in Times of Change: Stereotypes and Counter-Stereotypes of Leadership Discourse. In Challenging Leadership Stereotypes Through Discourse: Power, Management and Gender, eds. Cornelia Ilie and Stephanie Schnurr, 69-94. Singapore: Springer.

Karlsson, Paula, and Jenny Rutgersson. 2014. Communication in CEO Letters Before, During and After the Great Financial Crisis in 2008. A Study of Two Companies in the Real Estate Industry in $\quad$ Sweden. 01.03 .2020 <https://gupea.ub.gu.se/bitstream/2077/36110/1/gupea_2077_ 36110_1.pdf>. (accessed 13 May 2020).

Ke, Ping. 2018. Contrastive Linguistics. Singapore: Springer.

Kong, Kenneth. 2014. Professional Discourse. Cambridge: Cambridge University Press.

Kranich, Svenja. 2016. Contrastive Pragmatics and Translation. Evaluation, Epistemic Modality and Communicative Styles in English and German. Amsterdam: John Benjamins.

Lakoff, George. 2009. The Political Mind: A Cognitive Scientist's Guide to Your Brain and Its Politics. New York: Penguin. 
Pietro Manzella: "Dear Emma”... Genre Overlapping...

Liu, Shuang, Zala Volcic and Cindy Gallois. 2015. Introducing Intercultural Communication: Global Cultures and Contexts. London: Sage.

Loewenstein, Jeffrey, William Ocasio and Candace, Jones. 2012.

Vocabularies and Vocabulary Structure: A New Approach Linking Categories, Practices, and Institutions. The Academy of Management Annals 6: 41-86.

Magnusson, Lars and Stråth, Bo. 2016. A Brief History of Political Economy: Tales of Marx, Keynes and Hayek. Cheltenham, UK (Cheltenham, UK, and Northampton, MA): Edward Elgar.

Malavasi, Donatella. 2011. 'Doing Well by Doing Good': A Comparative Analysis of Nokia's and Ericsson's Corporate Social Responsibility Reports. In Discourse, Communication and the Enterprise: Genres and Trends, eds. Giuliana Garzone and Maurizio Gotti, 193-212. Bern: Peter Lang.

Morrow, Cynthia B., Douglas Hirano and Brad Christensen. 2008. Communication and Media Relations. In Public Health Administration: Principles for Population-Based Management, eds. Lloyd F. Novick, Cynthia B. Morrow and Glen P. Mays, 567-588. Boston: Jones and Bartlett.

Murphy, Amanda C. 2015. On 'True' Portraits of Letters to Shareholders - and the Importance of Phraseological Analysis. In Current Issues in Phraseology, eds. Sebastian Hoffmann, Bettina Fischer-Starcke and Andrea Sand, 57-82. Amsterdam: John Benjamins.

Neumann, Stella. 2014. Contrastive Register Variation- A Quantitative Approach to the Comparison of English and German. Berlin: De Gruyter Mouton.

Ngai, Cindy Sing-Bik, and Rita Gill. 2014. Communication with Stakeholders through Corporate Web Sites: An Exploratory Study on the CEO Messages of Major Corporations in Greater China. Journal of Business and Technical Communication 28: 352-394.

Schnitzer, Johannes. 2017. The Annual Report. In Handbook of Business Communication: Linguistic Approaches, eds. Gerlinde Mautner and Franz Rainer, 197-218. Berlin: De Gruyter Mouton.

Schubert, Klaus. 2007. Wissen, Sprache, Medium, Arbeit. Ein integratives Modell der ein- und mehrsprachigen Fachkommunikation. Tübingen: Narr. 
Shuttleworth, Mark and Cowie Moira. 2014. Dictionary of Translation Studies. Abingdon: Routledge.

Stråth, Boed. 2000. After Full Employment: European Discourses on Work and Flexibility. Brussels: Peter Lang.

Wallwork, Adrian. 2016. English for Presentations at International Conferences. Cham: Springer.

Zoppei, Verena. 2017. Anti-money Laundering Law: Socio-legal Perspectives on the Effectiveness of German Practices. Berlin: Springer.

- APPENDIX A (ATTACHED):

MARCHIONNE'S LETTER TO EMMA MARCEGAGLIA (ENGLISH VERSION).

- APPENDIX B (ATTACHED):

MARCHIONNE'S LETTER TO EMMA MARCEGAGLIA (ITALIAN VERSION). 


\section{Pietro Manzella: “Dear Emma”... Genre Overlapping...}

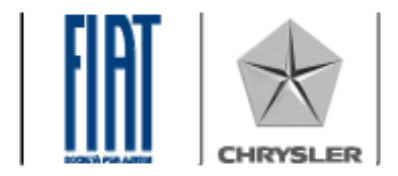

\section{Letter from Sergio Marchionne to Emma Marcegaglia}

On Friday, September $30^{\text {th }}$, CEO of Fiat S.p.A. and Chairman of Fiat Industrial S.p.A., Sergio Marchionne, sent two identical letters to the President of Confindustria, Emma Marcegaglia. Following is the content of those letters.

Dear Emma,

In recent months, after years of inaction, two important decisions were taken in this country with the objective of creating the conditions necessary to revitalize our economic system.

I am referring to the interconfederate agreement signed by national trade unions on June $28^{\text {th }}$ and promoted by Confindustria, and, even more important, the passing of Article 8 by Parliament that provides essential mechanisms for labor flexibility, in addition to extending the validity of the June $28^{\mathrm{t}}$ agreement to agreements reached prior to that date.

Fiat was immediate in expressing its unreserved appreciation to the government, Confindustria and trade unions for the two provisions that would resolve many sticking points in relations with the trade unions and provide the certainties necessary to this nation's economic development. At a particularly difficult time for the global economy, this new framework would have enabled all Italian businesses to compete internationally under conditions that are less disadvantageous in comparison with those of our competitors.

However, the signing of the interconfederate agreement of September $21^{\text {st }}$ sparked a heated debate that - as a result of the contradictory positions subsequently taken and even declarations by some of their intention not to apply those agreements in practice - has significantly diminished confidence in the effectiveness of Article 8.

There is a risk, therefore, that the effectiveness of the mechanisms provided under the new legislation will be undermined and operating flexibility severely limited.

Fiat, which is engaged in the creation of a major international group with 181 plants in 30 countries, cannot afford to operate in Italy in an environment of uncertainty that is so incongruous with the conditions that exist elsewhere in the industrialized world.

It is for these reasons, none of which are politically motivated or connected to our future investment plans, that I am hereby confirming that, as indicated in our letter of June $30^{\text {th }}$, Fiat and Fiat Industrial have decided to withdraw from Confindustria with effect January $1^{*}, 2012$. We are evaluating the possibility of collaborating, in a form yet to be agreed, with several local/regional organizations belonging to Confindustria, including, in particular, the Unione Industriale di Torino.

On our side, we will exercise our freedom to rigorously apply the new legislative provisions. Relations with our employees and with the trade unions will be conducted in a manner that does not infringe on any rights of workers and in full respect of the roles of all concerned, consistent with the agreements already reached at Pomigliano, Mirafiori and Grugliasco.

This important decision was reached after long and careful consideration. It is a decision that we cannot back away from because we are committed to playing a leading role in the industrial development of this nation.

Yours sincerely,

Sergio Marchionne

Turin, October $3^{\text {rd }}, 2011$ 


\section{Comparative Legilinguistics 44/2020}

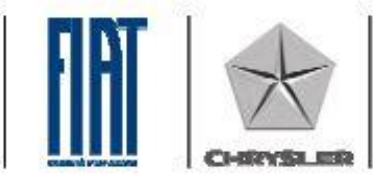

\section{Lettera di Sergio Marchionne a Emma Marcegaglia}

L'Amministratore Delegato di Fiat S.p.A. e Presidente di Fiat Industrial, Sergio Marchionne, ha inviato venerdi 30 settembre alla presidente di Confindustria, Emma Marcegaglia, due lettere identiche il cui contenuto viene di seguito riportato.

\section{Cara Emma,}

negli ultimi mesi, dopo anni di immobilismo, nel nostro Paese sono state prese due importanti decisioni con Pobiettivo di creare le condizioni per il rilancio del sistema economico.

Mi riferisco allaccordo interconfederale del 28 giugno, di cui Confindustria è stata promotrice, ma soprattutto all'approvazione da parte del Parlamento dell'Articolo 8 che prevede importanti strumenti di flessibilitá oltre all'estensione della validità dell'accordo interconfederale ad intese raggiunte prima del 28 giugno.

La Fiat fin dal primo momento ha dichiarato a Governo, Confindustria e Organizzazioni sindacali il pieno apprezzamento per $\mathrm{i}$ due provvedimenti che avrebbero risolto molti punti nodali nei rapporti sindacali garantendo le certezze necessarie per lo sviluppo economico del nostro Paese.

Questo nuovo quadro di riferimento, in un momento di particolare difficolta dell'economia mondiale, avrebbe permesso a tutte le imprese italiane di affrontare la competizione internazionale in condizioni meno sfavorevoli rispetto a quelle dei concorrenti.

Ma con la firma dell'accordo interconfederale del 21 settembre é iniziato un acceso dibattito che, con prese di posizione contraddittorie e addirittura con dichiarazioni di volonta di evitare l'applicazione degli accordi nella prassi quotidiana, ha fortemente ridimensionato le aspettative sull'efficacia dell'Articolo 8.

Si rischia quindi di snaturare limpianto previsto dalla nuova legge e di limitare fortemente la flessibilità gestionale.

Fiat, che è impegnata nella costruzione di un grande gruppo internazionale con 181 stabilimenti in 30 paesi, non puó permettersi di operare in Italia in un quadro di incertezze che la allontanano dalle condizioni esistenti in tutto il mondo industrializzato.

Per queste ragioni, che non sono politiche $e$ che non hanno nessun collegamento con i nostri futuri piani di investimento, ti confermo che, come preannunciato nella lettera del 30 giugno scorso, Fiat e Fiat Industrial hanno deciso di uscire da Confindustria con effetto dal 1 gennaio 2012. Stiamo valutando la possibilita di collaborare, in forme da concordare, con alcune organizzazioni territoriali di Confindustria e in particolare con I"Unione Industriale di Torino.

Da parte nostra, utilizzeremo la libertà di azione applicando in modo rigoroso le nuove disposizioni legislative. I rapporti con i nostri dipendenti e con le Organizzazioni sindacali saranno gestiti senza toccare alcun diritto dei lavoratori, nel pieno rispetto dei reciproci ruoli, come previsto dalle intese già raggiunte per Pomigliano, Mirafiori e Grugliasco.

$E^{\prime}$ una decisione importante, che abbiamo valutato con grande serieta e attenzione, alla quale non possiamo sottrarci perché non intendiamo rinunciare a essere protagonisti nello sviluppo industriale del nostro Paese.

Con i miei migliori saluti.

Sergio Marchionne

Torino, 3 ottobre 2011

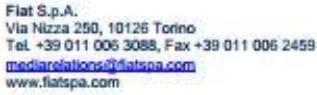

